\title{
Eco-Friendly Management of Tomato Fruit Borer, Helicoverpa armigera under Hill Condition, Uttrakhand, India
}

\author{
Sundar Pal ${ }^{1^{*}}$, D.K. Singh ${ }^{2}$, Ram Singh Umrao ${ }^{3}$ and Omendra Sharma ${ }^{3}$ \\ ${ }^{1}$ DBS College of Agricultur and Allied Science, Selaqui, Dehradun, Uttrakhand-248001, India \\ ${ }^{2}$ Department of Oilseed section, ${ }^{3}$ Department of Entomology, C.S.A.U.A. \& T., \\ Kanpur-208002, India \\ *Corresponding author
}

\section{A B S T R A C T}

\section{Keywords}

Helicoverpa armigera,

Tomato, efficacy,

Efficiency, Chemicals

Article Info

Accepted:

20 September 2018

Available Online:

10 October 2018
Seven insecticides tested against fruit borer, Helicoverpa armigera of tomato, Solanum lycopersicum under field condition. The efficiency of insecticides was similar effective after both sprays as indoxacarb 14.5SC > novaluron $10 \mathrm{EC}>\operatorname{spinosad} 45 \mathrm{EC}>$ rynaxypyr $20 \mathrm{SC}>$ nske $5 \%>$ nimbicidine $5 \%>$ neemoil $1 \%$ against reduction in fruit infestation. The maximum increased seed yield $(45.00 \mathrm{q} / \mathrm{ha})$ recorded from Indoxacarb 14.5 $\mathrm{SC}$ treated plots. The maximum cost benefit was return from Indoxacarb 14.5 SC treatment, Rs. 16 after per rupee investment.

\section{Introduction}

Tomato, Lycopersicon esculentum Mill is one of the most important vegetable of the country. India is one of the largest producers of tomatoes in the world, second only to China.

Around $11 \%$ of the total world produce of tomatoes is cultivated in India. All nutrients especially vitamin $\mathrm{C}, \mathrm{B}$ and $\mathrm{K}$ have good source in tomato. India have a total area under tomato cultivation are 773.88 thousand hectares and total production 18731.97 thousand MT during 2015-16 (Anonymous 2017). Tomato is a major vegetable widely produced throughout the Uttarakhand, where it is grown both in hills as well as in plains. Nainital, Dehradun, U.S. Nagar and Haridwar are the four major districts producing tomatoes and constitute about 63 percent of the total production in the state. The major insect pests of tomato are Helicoverpa armigera; Bemisia tabaci; Amrasca devastans; Liriomyza trifolii; Myzus persica and Epilachna dedecastigma (Sharma et al., 2013).

\section{Materials and Methods}

The present investigation was carried out at the Agriculture Farm of Doon School of Agriculture and Allied Science, Selaqui, Deharadun, Uttrakhand, India during rabi season 2016-17 and 2017-18. Tomato plants 
transplanted from nursery to field in Randomized Block Design in trice replication. A total of seven insecticides viz., neemoil 5\%, nimbicidine 5\%, NSKE 5\%, rynaxypyr 20SC@100ml ha ${ }^{-1}$, spinosad45 EC @ 75 g.a.i. ha ${ }^{-1}$, novaluron10 EC @ 100 g.a.i. ha 1 and indoxacarb14.5 SC@60 g.a.i. ha ${ }^{-1}$ were tested against Helicoverpa armigera in tomato crop. The chemical applied two times during study period with the help of Knapsack Sprayer at 20 days interval. The required quantity of chemical applied to the point of run-off for ensuring through coverage of the plant surface. The observations were recorded on fruit infestation from each plot at $3^{\text {rd }}, 7^{\text {th }}$ and $10^{\text {th }}$ DAA and calculated fruit infestation per cent. Other field practices timely conducted.

$$
\% \text { fruit infestation }=\frac{\text { Numbers of infested fruits }}{\text { Total numbers of fruits }} \times 100
$$

The calculation of benefit cost ratio as follows:

$$
\text { Marginal BCR }=\frac{\text { Net return (Rs.) }}{\text { Total cost of treatment (Rs. ha } \left.{ }^{-1}\right)}
$$

\section{Results and Discussion}

\section{Insecticidal efficacy against fruit infestation}

\section{After $1^{\text {st }}$ spray}

All the treatments were founded superior to the managing fruit infestation in tomato over the control after first spray. The mean fruit infestation per cent were decreased viz., $17.23 \pm 0.9,20.62 \pm 2.3,28.03 \pm 0.7,29.49 \pm 1.8$, $32.61 \pm 2.4,34.65 \pm 2.6$ and $42.60 \pm 1.7$ from $66.53 \pm 4.3,67.79 \pm 2.7,66.51 \pm 8.0,65.95 \pm 4.0$, $65.26 \pm 3.9,65.50 \pm 5.8$ and $66.24 \pm 1.2$ from indoxacarb, novaluron, spinosad, rynaxypyr, NSKE, nimbicidine and neemoil treated plots, respectively, after $3^{\text {rd }}$ DAS. The fruit infestation per cent over the control were show in increased order viz., 31.27, 44.09, 47.39, 52.41, 54.78, 66.74 and 72.21 from indoxacarb, novaluron, spinosad, rynaxypyr, NSKE, nimbicidine and neemoil treated plots, respectively, after $3^{\text {rd }}$ DAS. Kumar et al., (2017) found flubendiamide 480 SC was superior in recording lower larval population followed by indoxacarb $14.5 \mathrm{SC}$. The reduction in fruit infestation per cent was significantly superior over the control and a range was 16.12 $\pm 2.4-39.07 \pm 2.5$. Spinosad and rynaxypyr was not significantly different to over the control.

The maximum reduction in fruit infestation (73.29\%) was recorded from indoxacarb treated plots followed by novaluron $(69.22 \%)$, spinosad (63.67\%), rynaxypyr $(60.75 \%)$, NSKE (55.52\%), nimbicidine $(48.95 \%)$ and neemoil $(35.25 \%)$ over the control. Ravi et al., (2008) recorder that indoxacarb 14.5 SC was most effective and in reducing fruit infestation by $H$. armigera tomato crop.

The efficiency of the chemicals was similar and continues performance in reduction of fruit infestation against fruit borer in tomato just after $10^{\text {th }}$ DAS, but indoxacarb and novaluron were not significantly difference.

Hasan et al., (2016) observed that the percent fruit damage over the untreated control is concerned maximum reduction in damage $(83.17 \%)$ was obtained with Indoxacarb $75 \mathrm{~g}$ a.i./ha followed by Indoxacarb $60 \mathrm{~g}$ a.i./ha $(71.89 \%)$. Indoxacarb at 30, 40 and $50 \mathrm{~g}$ a.i. /ha reduced the per cent damage by 35.94 , 40.57 and 48.72 per cent respectively. Kumar et al., who reported that 18.50 to 32.64 per cent fruit losses could by avoided as results of sprays of insecticides. Wajid (2016) recorded minimum tomato fruit infestation was observed from indoxacarb treated field (Table 1-3). 
Table.1 Efficiency of insecticides after first spray against tomato fruit infestation by, Helicoverpa armigera

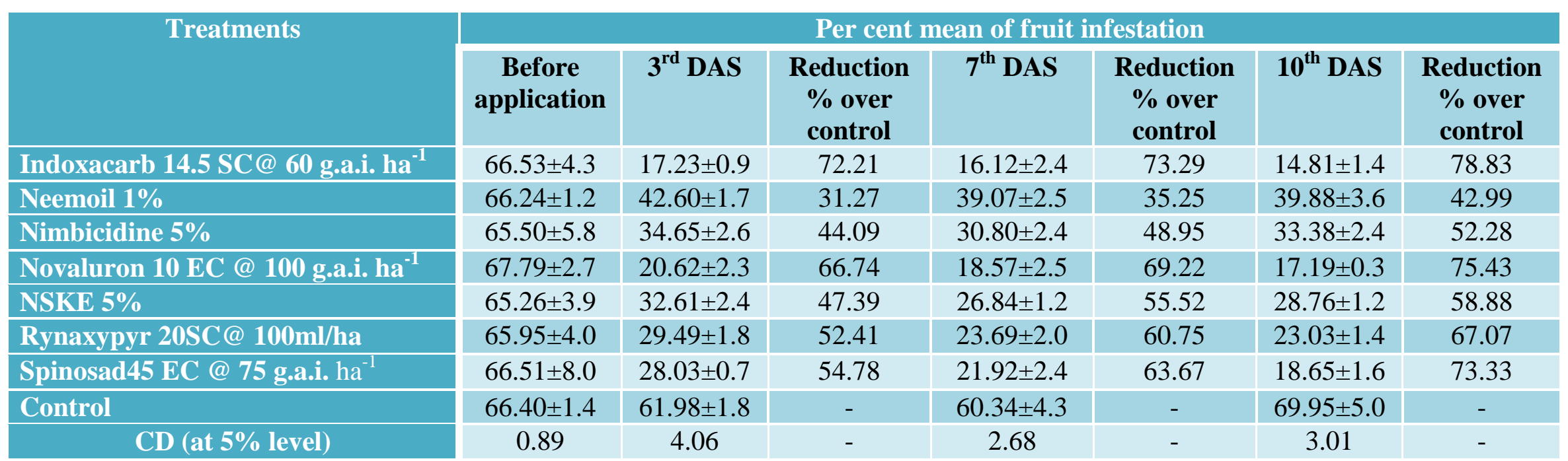

Table.2 Efficiency of insecticides after second spray against tomato fruit infestation by, Helicoverpa armigera

\begin{tabular}{|c|c|c|c|c|c|c|c|}
\hline \multirow[t]{2}{*}{ Treatments } & \multicolumn{7}{|c|}{ Per cent mean of fruit infestation } \\
\hline & $\begin{array}{c}\text { Before } \\
\text { application }\end{array}$ & $3^{\text {rd }}$ DAS & $\begin{array}{c}\text { Reduction } \\
\% \text { over } \\
\text { control }\end{array}$ & $7^{\text {th }}$ DAS & $\begin{array}{c}\text { Reduction } \\
\% \text { over } \\
\text { control }\end{array}$ & $10^{\text {th }}$ DAS & $\begin{array}{l}\text { Reduction } \\
\% \text { over } \\
\text { control }\end{array}$ \\
\hline Indoxacarb 14.5 SC@ 60 g.a.i. ha ${ }^{-1}$ & $61.83 \pm 4.1$ & $18.93 \pm 2.8$ & 73.45 & $6.64 \pm 0.8$ & 92.08 & $8.30 \pm 1.0$ & 89.61 \\
\hline Neemoil 1\% & $61.83 \pm 4.1$ & $46.35 \pm 4.7$ & 35.01 & $24.94 \pm 3.0$ & 70.24 & $26.42 \pm 2.0$ & 68.24 \\
\hline Nimbicidine $\mathbf{5 \%}$ & $65.56 \pm 8.6$ & $41.24 \pm 1.6$ & 42.16 & $19.15 \pm 1.5$ & 77.15 & $21.48 \pm 0.6$ & 74.07 \\
\hline Novaluron 10 EC @ 100 g.a.i. ha ${ }^{-1}$ & $65.56 \pm 8.6$ & $26.45 \pm 3.0$ & 62.91 & $11.50 \pm 1.7$ & 86.28 & $10.78 \pm 1.0$ & 86.69 \\
\hline NSKE 5\% & $61.83 \pm 4.1$ & $35.02 \pm 0.8$ & 50.90 & $15.38 \pm 1.7$ & 81.64 & $17.31 \pm 1.1$ & 78.99 \\
\hline Rynaxypyr 20SC@ 100ml/ha & $64.21 \pm 3.3$ & $31.30 \pm 1.4$ & 56.10 & $15.27 \pm 0.9$ & 81.78 & $14.06 \pm 0.8$ & 82.82 \\
\hline Spinosad45 EC @ 75 g.a.i. ha ${ }^{-1}$ & $62.22 \pm 6.1$ & $28.83 \pm 1.7$ & 59.57 & $12.52 \pm 1.6$ & 85.07 & $12.39 \pm 1.4$ & 84.79 \\
\hline Control & $65.16 \pm 7.4$ & $71.31 \pm 1.8$ & - & $83.81 \pm 1.7$ & - & $84.30 \pm 2.2$ & - \\
\hline CD (at 5\% level) & 3.58 & 3.61 & - & 2.01 & - & 2.14 & - \\
\hline
\end{tabular}




\section{Int.J.Curr.Microbiol.App.Sci (2018) 7(10): 3008-3013}

Table.3 Pooled economics analysis of insecticidal efficacy in tomato crop against Helicoverpa armigera during 2016-17 and 2017-18

\begin{tabular}{|c|c|c|c|c|c|c|c|}
\hline $\begin{array}{l}\text { S. } \\
\text { No. }\end{array}$ & Treatment & $\begin{array}{l}\text { Total cost of } \\
\text { treatment } \\
(\mathrm{Rs} / \mathrm{ha})^{*}\end{array}$ & $\begin{array}{l}\text { Yield } \\
\text { (q/ha) }\end{array}$ & $\begin{array}{l}\text { Increase } \\
\text { yield } \\
\text { (q/ha) }\end{array}$ & $\begin{array}{c}\text { Value of } \\
\text { increase yield } \\
(\mathrm{Rs} / \mathrm{ha})^{\#}\end{array}$ & $\begin{array}{l}\text { Net return } \\
\text { (Rs.) }\end{array}$ & CBR \\
\hline 1. & Indoxacarb14.5 SC@60 g.a.i. ha ${ }^{-1}$ & 3812.50 & 305.50 & 45.00 & 65250.00 & 61437.50 & $1: 16$ \\
\hline 2. & Neemoil $5 \%$ & 3254.25 & 265.50 & 05.00 & 07250.00 & 03995.75 & $1: 1$ \\
\hline 3. & Nimbicidine $5 \%$ & 3478.50 & 270.11 & 09.61 & 13934.50 & 10456.00 & $1: 3$ \\
\hline 4. & Novaluron 10 EC @ 100 g.a.i. ha ${ }^{-1}$ & 3525.50 & 299.25 & 38.75 & 56187.50 & 52662.00 & $1: 15$ \\
\hline 5. & NSKE $5 \%$ & 3594.50 & 272.35 & 11.85 & 17182.50 & 13588.00 & $1: 4$ \\
\hline 6. & Rynaxypyr 20SC@100ml ha ${ }^{-1}$ & 2939.50 & 280.25 & 19.75 & 28637.50 & 25698.00 & $1: 9$ \\
\hline 7. & Spinosad45 EC @ 75 g.a.i. ha ${ }^{-1}$ & 3550.50 & 290.25 & 29.75 & 43137.50 & 39587.00 & $1: 11$ \\
\hline 8. & Control & - & 260.50 & - & - & - & - \\
\hline
\end{tabular}

$*($ Including =labor charge + machine charge + insecticide cost $),{ }^{\#}\left(\right.$ Rs. $\left.14.50 \mathrm{~kg}^{-1}\right)$. 


\section{After $2^{\text {nd }}$ spray}

Observation on fruit infestation in tomato before second spray was not significant difference in fruit infestation in each plot after second spray and data collected at $3^{\text {rd }}$ day after spray (DAS) of insecticides that were significantly difference. The mean per cent fruit infestation were recorded from neemoil, nimbicidine, NSKE, rynaxypyr, spinosad, novaluron and indoxacarb treated plots after $1^{\text {st }}$ spray at $3^{\text {rd }}$ DAS viz., $46.35 \pm 4.7$, $41.24 \pm 1.6,35.02 \pm 0.8,31.30 \pm 1.4,28.83 \pm 1.7$, $26.45 \pm 3.0$ and $18.93 \pm 2.8$ followed by $61.83 \pm 4.1,65.56 \pm 8.6,61.83 \pm 4.1,64.21 \pm 3.3$, $62.22 \pm 6.1,65.56 \pm 8.6$ and $61.83 \pm 4.1$ before spray, respectively. The fruit infestation reduction per cent over the control in ascending order, 35.01, 42.16, 50.90, 56.10, 59.57, 62.91 and 73.45 from neemoil, nimbicidine, NSKE, rynaxypyr, spinosad, novaluron and indoxacarb treated plots, respectively. Second observation noticed at $7^{\text {th }}$ DAS. The maximum mean fruit infestation per cent reduction recorded from indoxacarb treated plots with $92.08 \%(6.64 \pm 0.8)$ over the control, where minimum fruit infestation was recorded from neem oil treated plots with $70.24 \%$ (24.94 \pm 3.0$)$ over the control.

Novaluran \& spinosad and rynaxypyr \& NSKE were equally significantly over the control. Kolarath et al., (2015) recorded that the novaluron was best result followed by spinosad and rynaxypyr against bod borer in field bean where similar result was found by Ghosh et al., (2010). Data recorded on fruit infestation at $10^{\text {th }}$ DAS in descending order viz., $\quad 26.42 \pm 2.0, \quad 21.48 \pm 0.6, \quad 17.31 \pm 1.1$, $14.06 \pm 0.8, \quad 12.39 \pm 1.4, \quad 10.78 \pm 1.0 \quad$ and $8.30 \pm 1.0$ from neem oil, nimbicidine, NSKE, rynaxypyr, spinosad, novaluron and indoxacarb treated plots, respectively, where fruit infestation reduction over the control were $68.24,74.07,78.99,82.82,84.79,86.69$ and 89.61 per cent, respectively.

\section{Marginal benefit cost ratio}

The crop yields of tomato from all treated plots were increase over the control. The field yield were recorded in ascending order viz., $5.00,9.61,11.85,19.75,29.75,38.75$ and $45.00 \mathrm{q}^{-1}$ from neemoil, nimbicidine, NSKE, rynaxypyr, spinosad, novaluron and indoxacarb treated plots. The maximum value of increased yield was recorded from indoxacarb with Rs. $65250.00 \mathrm{ha}^{-1}$ followed by other treatments. The maximum return was indoxacarb treatment plots viz., Rs. 16 after each rupee investment followed by novaluron (Rs. 15), spinosad (Rs.11), rynaxypyr (Rs.9), NSKE (Rs.4), nimbicidine (Rs.3) and neemol (Rs.1). Kumar et al., (2017) were recorded that the highest grain yield (928 kg ha-1) as well as cost benefit ratio (1:9.57) was obtained from the treatment flubendiamide $480 \mathrm{SC}$ and followed by indoxacarb 14.5 SC. Hasan et al., (2016) recorded that the indoxacarb treated treatments at 60 and $70 \mathrm{~g}$ a.i. /ha dosage yielded the highest yield of marketable fruits 29.16 and 29.50 tons/ ha respectively. While in untreated control, it was 16.66 tons/ha. Aheer et al., 1998() reported 72.19 to 77.79 per cent yield losses.

\section{Acknowledgement}

I am highly thankful to the Chairman, DBS College of Agriculture and Allied Science, Selaqui, Dehradun, Uttrakhand for partially supported to carry out the research work. My thankfulness also goes to Principal and other staff members of the college, who provided insight and expertise that greatly assisted the research.

\section{References}

Aheer GM, Muhammad L, Muhammad S. (1998). Quantitative losses of tomato fruits caused by tomato fruit borer, 
Heliothis armigera (Hub.). Pak. Entomologist.; 20(1/2):87-88.

Anonymous (2017). Horticultural Statistics at a Glance 2017. Department of Agriculture, Cooperation \& Farmers Welfare Ministry of Agriculture \& Farmers Welfare Government of India. Pp-473.

Ghosh, A., Chatterjee, M. and Roy, A. (2010). Bio-efficacy of spinosad against tomato fruit borer (Helicoverpa armigera Hub.) (Lepidoptera: Noctuidae) and its natural enemies. Journal of Horticulture and Forestry; 2(5): 108-111

Hasan W, Chhibber RC, Singh CP (2016) Effect of Indoxacarb against Tomato Fruit Borer (Helicoverpa armigera Hub.) and Phytotoxicity to Tomato Plants. Adv Plants Agric Res 3(2): 93.

Kumar J, Sharma SD, Jamwal RS. Estimation of avoidable yield loss due to fruit borer, Helicoverpa armigera (Hub.) in tomato planted at different dates in lower Kulluvally, Himachal Pradesh. Pest Mgmt. Econ. Zool. 1999; 7(2):155159.
Kumar, S., G. Singh, S. Kumar and A. Kumar (2017). Evaluation of some novel insecticides against Helicoverpa armigera (Hubner) in black gram (Vigna mungo). Journal of Entomology and Zoology Studies; 5(3): 183-185.

Ravi, M., Santharam, G. and Sathiah, N. (2008). Ecofriendly management of tomato fruit borer, Helicoverpa armigera (Hubner). Journal of Biopesticides; 1(2): 134-137.

Remya Kolarath, Shekharappa, R. A. Balikai E, B. S. Nandihalli and Y. N. Havaldar (2015). Evaluation of newer insecticides for the management of pod borers of field bean, Lablab purpureus (L.) Sweet. Karnataka J. Agric. Sci., 28(1): 107-109.

Sharma, D., Maqbool A., Ahmad H. and Jamwal V. V. S. (2013). Meteorological factors influencing insect pests of tomato. Ann. Pl. Protec.Sci. 21: 68-71.

Wajid Hasan (2016). Effect of indoxacarb against Tomato fruit borer (Helicoverpa armigera Hub.) and phytotoxicity to tomato plants. Advances in Plant \& Agriculture Research, 3 (2): 00093.

\section{How to cite this article:}

Sundar Pal, D.K. Singh, Ram Singh Umrao and Omendra Sharma. 2018. Eco-Friendly Management of Tomato Fruit Borer, Helicoverpa armigera under Hill Condition, Uttrakhand, India. Int.J.Curr.Microbiol.App.Sci. 7(10): 3008-3013. doi: https://doi.org/10.20546/ijcmas.2018.710.350 